\title{
Analysis of Financial Performance of Different Brands of Nisarga Winery-A Case Study
}

\author{
Pavitra Balundagi* and G. G. Joshi \\ Department of Agricultural Economics, Mahatma Phule Krishi Vidyapeeth, Rahuri, \\ (Maharashtra), India \\ *Corresponding author
}

\section{A B S T R A C T}

\section{Keywords}

Production cost, Financial ratio, B:C ratio

\section{Article Info}

Accepted:

12 December 2020

Available Online:

10 January 2021
The government of Karnataka has announced wine policy, as result of which many wine yards were established. Nisarga winery in Vijaypur district was one such unit. The specific objective of the study is to estimate the financial performance of the unit. The primary data for the year 2017- 18 was collected from the general manager of the unit. The financial ratio analysis, descriptive statistics were used for the study. There are 7 different brands in total, viz., Nisarga (Red and White wine), Samurai (Red and White wine) and Viraat (2 Red and 1 White Wine). There is a production of both red and white wine. The per liter production cost is more or less same for different brands. It is highest for Viraat under white wine i.e., Rs. 186.87 followed by Samurai under red wine i.e. Rs. 186.57. The Nisarga wine brands are in profit range. They have adequate capacity to recover their initial investment. In this study benefit cost ratio was noticed highest under red wine that is for every one rupee investment you get Rs. 2.34 (1:2.34) for Viraat B followed by 2.25 $(1: 2.25)$ for Viraat A. Comparatively it is less for white wine where it is least for Samurai that is Rs.1.36 followed by Nisarga that is Rs.1.49 (1:1.49).

\section{Introduction}

\section{General}

Historically, grapevine (Vitis vinifera L.) is grown mostly for wine making in the world over. In India on the contrary, remarkable success has been achieved in table grape production and yield levels of fresh grapes are highest in the world.

According to the table FAO data (2010) shows that, the leading grape producing countries in the world in terms of production are China (8651.83 thousand tons), Italy (7787.80 thousand tons), USA (6777.73 thousand tons) and Spain (6107.20 thousand tons). India's high productivity in grape has made it to reach 18th position in the world as far as production is concerned.

Table 1.2 shows that Maharashtra, Karnataka and Andhra Pradesh hold first, second and third position in the country in production, productivity and area of grapes. In India during 2016- 17 Total area under grapes was 
122.00 thousand hectares, production was 2634.74 thousand metric tonnes and productivity was 19.74 metric tonnes.

Table 1.3 represents that There is an increase in Area under grape production in Karnataka from 2001-05 to 2013-14 and in production and productivity no constant increase or decrease rates. Apart from this According to the report given from Gus trompiz in Business insider in 2017, in overall concern Production in Australia was expected to rise 6 per cent to 13.9 million hectoliters while Argentina was projected to post a 25 per cent jump to 11.8 million after a weather hit.

\section{Nisarga Wine Industry Vijaypur}

This Nisarga vineyard Pvt. Ltd is established in the year 2009-10 and it is located at Halagani village, adjacent to highway connecting the Vijaypur and Belgaum town and is just $25 \mathrm{~km}$ away from Vijaypur city limits measuring five acres. The unit will produce both White wine and Red wine. There are total seven brands under the process. The production has been started in the year 2010 with a production of 386075 liters and in 2017-18 it is 358851 liters.

\section{Materials and Methods}

\section{Selection of the study area}

The choice of Vijaypur district of North Karnataka was purposive, as more grape wineries were located and the huge area is under grape cultivation. Hence Nisarga wine industry is selected as it has better economic feasibility and profitable margin.

\section{Collection of Data}

Secondary data for the year 2017-18 regarding the Production, sales, financial information, production and marketing cost of the Grape wines was collected by survey method through personal interview with the manager of unit with the help of presented questionnaire. The efforts were made to prepare report with the manager through the personal assistance of owner and other supervisors. The data were collected in January 2019.

\section{Sources of Data}

The study contemplates to assess the performance of Wine unit in Vijaypur Dist. of Karnataka. Obviously, the data were required on various factors of different wines which were being produced in that unit.

\section{The major aspects of data requirements were as under}

Primary information of the unit.

Details of production and sale of grape wine.

Initial investment of the unit.

Fixed and operating cost of the unit.

Repairs and maintenance cost.

Fees, taxes, insurance and other relevant expenses.

Labours, supervisory staff and decision makers engaged with their bills, salaries and allowances.

Problems encountered by the unit in acquisition of raw materials, production and marketing processes.

Data was collected from the available records, registers of the Nisarga wine industry through discussion with the management.

\section{Method of analysis}

To facilitate the analysis of data, the sample of wine is divided into Red and white with different brands and they are again categorized according to their capacity ranges 750,375 and $180 \mathrm{ml}$.

The data collected from the unit was compiled according to their individual brands. The data 
so compiled was further analyzed to obtain averages related to different aspects.

\section{Financial performance analysis}

\section{Break even analysis}

The break-even point is the level of operation at which total revenue equals to total costs. The break-even quantity is estimated by using the formula, it was taken from the report Corporate finance and accounting report given by Chris murphy in 2019 .

$$
\begin{array}{r}
\mathrm{BEQ}= \\
-\mathrm{TFC} \\
-\mathrm{P}-\mathrm{VC}
\end{array}
$$

Where,

$\mathrm{BEQ}=$ Break even quantity

TFC = Total annual fixed cost (Rs.) $\mathrm{P}=$ Price per liter produced (Rs.)

$\mathrm{VC}=$ variable cost per liter produced (Rs.)

\section{Net present value}

It is simply the present worth of cash flow stream. The selection criterion of the current NPV is estimated by using the following equation,

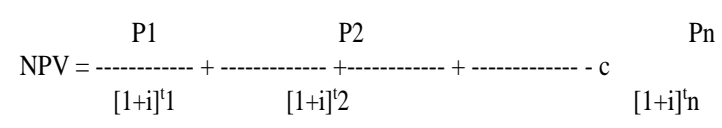

Where,

$\mathrm{P}=$ Net cash flow $\mathrm{i}=$ Discount rate $\mathrm{t}=$ Time period

$\mathrm{c}=$ Initial cost of investment

\section{Internal rate of return}

The internal rate of return of an industry is the discount rate, which makes net present value equal to zero. It was calculated by using the formula.

IRR $=$ Lower discount rate + Difference between the two-discount rate (NPV at lower discount rate + Absolute difference between NPV at two different discount rate).

\section{Payback period}

Payback period (PP) is the number of years it takes for a company to recover its original investment in a project, when net cash flow equals zero. In the calculation of the payback period, the cash flows of the project are estimated. The payback period is then a simple calculation. It was taken from the report Corporate finance and accounting report given by Chris murphy in 2019 .

$$
\text { PP = Years full recovery }+ \text { - } \begin{gathered}
\text { Unrecovered cost at beginning of last year } \\
\text { Cas flow in following year }
\end{gathered}
$$

\section{Results and Discussion}

The activity that is processing of grapes into wine being an important economic aspect in realizing the better price for the Agricultural product, the study of economic evaluation of Nisarga wine industry becomes an important activity. To study performance evaluation and managerial aspects of the unit some results were discussed below. In this chapter the economic performance of Nisarga Wine was studied. Therefore, an attempt has made in this chapter to study the given objective of the Wine unit which was enlisted below.

The results of the study are discussed in this chapter as under the following heading

The financial performance of grape winery

The information regarding total returns and $\mathrm{B}: \mathrm{C}$ ratio of different wines is represented in Table 4.1.

It is observed from the table that total cost 
incurred for the production of both red and white wine is Rs. 546 lakhs. Among that 75.47 per cent share is from red wine and 24.53 per cent share is from white wine. Maximum B:C ratio was noticed for Viraat B that is 2.34 followed by Viraat A (2.25), Nisarga (1.85) and Samurai (1.68) in red wine and it is least for Samurai (1.36) followed by Nisarga (1.49) and Viraat (1.59) in white wine. It is also noticed that total returns were Rs. 1033.33 lakhs. Among that major contributors are Viraat A (34.83\%) followed by Nisarga (19.28\%), Samurai $(16.44 \%)$ and Viraat B in red wine and Viraat $(8.23 \%)$ followed by Nisarga (6.03\%) and Samurai $(5.14 \%)$ in white wine. The sme study was conducted by G.G. Joshi, D.J. Sanap and J.T. Dorge in the report Economics of production and marketing of Sula-wine: A case study which was published in Indian journal of Economics and development (2016).

Table.1.1 Major Grape producing countries in the World (2010)

\begin{tabular}{|c|c|c|c|c|}
\hline Country & Area(ha) & Production(tonnes) & $\begin{array}{l}\text { Productivity(to } \\
\text { nnes) }\end{array}$ & $\begin{array}{l}\text { Per cent share of } \\
\text { world in Production }\end{array}$ \\
\hline China & 533137 & 8651831 & 134263 & 12.89 \\
\hline Italy & 777500 & 7787800 & 59316 & 11.60 \\
\hline USA & 8001 & 6777730 & 195000 & 10.10 \\
\hline Spain & 14942 & 6107200 & 174616 & 9.10 \\
\hline France & 787133 & 5848960 & 100997 & 8.71 \\
\hline Turkey & 19000 & 4255000 & 15625 & 6.34 \\
\hline Chile & 188220 & 2755700 & 162282 & 4.11 \\
\hline Argentina & 223685 & 2616610 & 116977 & 3.90 \\
\hline Iran & 220836 & 2255670 & 100165 & 3.36 \\
\hline Australia & 163785 & 1684350 & 102839 & 2.51 \\
\hline Other countries & 4168293 & 18375404 & 6575047 & 27.38 \\
\hline World total & 7104512 & 67116255 & 7737127 & 100.00 \\
\hline
\end{tabular}

Source: FAO data (2010)

Table.1.2 Top grape producing countries in India (2016-17)

\begin{tabular}{|c|c|c|c|}
\hline States & $\begin{array}{c}\text { Area } \\
(\mathbf{0 0 0} \text { ha) }\end{array}$ & $\begin{array}{c}\text { Production } \\
(\mathbf{0 0 0} \text { MT) }\end{array}$ & $\begin{array}{c}\text { Productivit } \\
\text { y (In }\end{array}$ \\
\hline Maharashtra & 90.36 & 2074.02 & $\mathbf{2 0 . 5 6}$ \\
\hline Karnataka & 24.23 & 445.89 & $\mathbf{1 8 . 4 0}$ \\
\hline Andhra Pradesh & 0.83 & 16.62 & $\mathbf{2 0 . 0 0}$ \\
\hline Tamil Nadu & 2.44 & 34.10 & $\mathbf{1 3 . 2 7}$ \\
\hline Punjab & 0.30 & 8.49 & $\mathbf{2 8 . 3 9}$ \\
\hline Haryana & 0.04 & 0.20 & $\mathbf{5 . 1 6}$ \\
\hline Uttar Pradesh & 0.02 & 0.10 & $\mathbf{3 . 0 0}$ \\
\hline Rajasthan & 0.01 & 0.02 & $\mathbf{1 5 . 0 0}$ \\
\hline Madya Pradesh & $\mathbf{0 . 1 6}$ & $\mathbf{3 . 0 0}$ & $\mathbf{1 9 . 7 4}$ \\
\hline Total in India & $\mathbf{1 2 2 . 8 8}$ & $\mathbf{2 6 3 4 . 7 4}$ & \\
\hline
\end{tabular}

Source: www.Indiastat.com (2018) 
Table.1.3 Area, production and productivity of Grapes in Karnataka

\begin{tabular}{|c|c|c|c|}
\hline Years & $\begin{array}{c}\text { Area } \\
(\text { ha) }\end{array}$ & $\begin{array}{c}\text { Production } \\
\text { (In tonnes) }\end{array}$ & $\begin{array}{c}\text { Productivity } \\
\text { (Kgs/Ha) }\end{array}$ \\
\hline $\mathbf{2 0 0 4 - 0 5}$ & 9406 & 243329 & $\mathbf{2 5 8 6 9}$ \\
\hline $\mathbf{2 0 0 5 - 0 6}$ & 5903 & 176796 & $\mathbf{2 9 9 5 0}$ \\
\hline $\mathbf{2 0 0 6 - 0 7}$ & 11991 & 327513 & $\mathbf{2 7 3 1 3}$ \\
\hline $\mathbf{2 0 0 7 - 0 8}$ & 10029 & 265199 & $\mathbf{2 6 4 4 2}$ \\
\hline $\mathbf{2 0 0 8 - 0 9}$ & 12894 & 325199 & $\mathbf{2 5 2 2 1}$ \\
\hline $\mathbf{2 0 0 9 - 1 0}$ & 12221 & 381955 & $\mathbf{3 1 2 5 4}$ \\
\hline $\mathbf{2 0 1 0 - 1 1}$ & 13634 & 544351 & $\mathbf{3 9 9 2 6}$ \\
\hline $\mathbf{2 0 1 1 - 1 2}$ & 15678 & 674703 & $\mathbf{4 3 0 3 5}$ \\
\hline $\mathbf{2 0 1 2 - 1 3}$ & $\mathbf{1 8 3 4 8}$ & 822085 & $\mathbf{4 4 8 0 5}$ \\
\hline $\mathbf{2 0 1 3 - 1 4}$ & $\mathbf{1 8 1 8 7}$ & $\mathbf{6 7 9 3 7 8}$ & $\mathbf{3 7 3 5 5}$ \\
\hline
\end{tabular}

Source: www.indiastat.com

Table.4.1 Total returns, Costs and B:C ratio of different varieties of wines

\begin{tabular}{|c|c|c|c|c|c|}
\hline Different wines & $\begin{array}{c}\text { Total production } \\
\text { ('000 liters) }\end{array}$ & $\begin{array}{l}\text { Rate/ } \\
\text { liter } \\
\text { (in Rs.) }\end{array}$ & $\begin{array}{l}\text { Total } \\
\text { return } \\
\text { (in Rs. }\end{array}$ & $\begin{array}{l}\text { Total cost } \\
\quad \text { (in } \\
\text { Rs. lakhs) }\end{array}$ & $\begin{array}{l}\text { B:C } \\
\text { Ratio }\end{array}$ \\
\hline \multicolumn{6}{|l|}{ Red wine } \\
\hline \multirow[t]{2}{*}{ Nisarga } & \multirow[t]{2}{*}{60.75} & \multirow[t]{2}{*}{328.00} & 199.26 & 107.47 & \multirow[t]{2}{*}{1.85} \\
\hline & & & (19.28) & (19.68) & \\
\hline \multirow[t]{2}{*}{ Samurai } & \multirow[t]{2}{*}{54.00} & \multirow[t]{2}{*}{314.66} & 169.91 & 100.75 & \multirow[t]{2}{*}{1.68} \\
\hline & & & (16.44) & (18.45) & \\
\hline \multirow[t]{2}{*}{ Viraat (A) } & \multirow[t]{2}{*}{135.00} & \multirow[t]{2}{*}{266.66} & 359.99 & 159.85 & \multirow[t]{2}{*}{2.25} \\
\hline & & & (34.83) & (29.27) & \\
\hline Viraat (B) & 37.26 & 277.77 & 103.48 & 44.08 & 2.34 \\
\hline \multicolumn{6}{|l|}{ White wine } \\
\hline \multirow[t]{2}{*}{ Nisarga } & \multirow[t]{2}{*}{22.50} & \multirow[t]{2}{*}{277.33} & 62.39 & 41.64 & \multirow{2}{*}{1.49} \\
\hline & & & (6.03) & (7.62) & \\
\hline \multirow[t]{2}{*}{ Samurai } & \multirow[t]{2}{*}{21.00} & \multirow[t]{2}{*}{253.33} & 53.19 & 38.95 & \multirow[t]{2}{*}{1.36} \\
\hline & & & $(514)$ & $(7$ 13) & \\
\hline \multirow[t]{2}{*}{ Viraat } & \multirow[t]{2}{*}{28.50} & \multirow[t]{2}{*}{298.66} & 85.11 & 53.26 & \multirow[t]{2}{*}{1.59} \\
\hline & & & (8.23) & $(9.75)$ & \\
\hline Total & 359.00 & & 1033.33 & 546.00 & \\
\hline
\end{tabular}


Table.4.2 Break even analysis

\begin{tabular}{|c|l|c|c|}
\hline Sl. No & Wines & $\begin{array}{c}\text { Total production } \\
(\cdot \mathbf{0 0 0} \text { liters })\end{array}$ & $\begin{array}{c}\text { Break even analysis } \\
\text { ('000 liters) }\end{array}$ \\
\hline Red wine & & \multicolumn{2}{|c|}{} \\
\hline $\mathbf{1}$ & Nisarga & 60.75 & $\mathbf{1 6 . 6 6}$ \\
\hline $\mathbf{2}$ & Samurai & 54.00 & $\mathbf{1 7 . 2 7}$ \\
\hline $\mathbf{3}$ & Viraat (A) & 135.00 & $\mathbf{3 9 . 0 8}$ \\
\hline $\mathbf{4}$ & Viraat (B) & 37.26 & $\mathbf{1 0 . 2 3}$ \\
\hline White wine & & & $\mathbf{8 . 8 4}$ \\
\hline $\mathbf{4}$ & Nisarga & 22.50 & $\mathbf{9 . 8 4}$ \\
\hline $\mathbf{5}$ & Samurai & 21.00 & $\mathbf{9 . 9 9}$ \\
\hline $\mathbf{6}$ & Viraat & $\mathbf{2 8 . 5 0}$ & \\
\hline
\end{tabular}

Break even analysis for different varieties of wines

The information regarding break even analysis is represented in the Table 4.2.

It is observed from the table that; the unit produces more than its break-even quantity for all types of different wines. So, it can be depicted that all the brands are under risk free conditions and their value has been overtaken by their respective production levels.

In conclusion,

The Nisarga winery firm started in 2009 produced grape wine of 386075 liters in 201011 which was 358851 in 2017-18. The compound annual growth rate of production of Nisarga wine worked out to be 1.94 per cent (NS) [Red wine 1.27NS and white wine $0.67 \mathrm{NS}$ ). The sale of the Nisarga winery increased was 371928 liters in 201011 to 188437 liters in 2017- 18 recording a compound annual growth rate of 1.86 per cent [1.13 per cent for Red wine and 0.73 per cent for white wine]. Around 96 per cent of wine produced was sold in the same year. The efficiency of resource use is 1.5 Kilogram og Grapes are required to produce one litre of wine i.e., 1 kilo gram of Grape gives 0.67 litres of Wine in this industry.

Nisarga winery offer 7 different brands of wine which comprises both red wine as well as the white wine. The brand names of the Nisarga winery are Nisarga, Samurai and Viraat. Cost amounted from the raw materials for red wine is Rs. 194.71 lakhs and for white wine it is Rs. 49.13 lakhs. Total cost amounted from raw materials for production of both red and white wine is Rs. 243.84 lakhs. In total wine production share of red wine was maximum i.e., 287 thousand liters $(79.94 \%)$ followed by white wine i.e. 72 thousand liters $(20.05 \%)$. Total production of wine from both red and white wine is 359 thousand liters.

Per liter production cost was highest for Viraat white wine i.e., Rs. 186.87 followed by Samurai red wine i.e., Rs. 186.57. Total number of bottles produced is highest for Nisarga red wine that is of $180 \mathrm{ml}$ capacity (207 thousand bottles). Per bottle production cost is highest for Viraat red wine of $750 \mathrm{ml}$ capacity i.e., Rs. 159.85. Price per bottle is highest for Nisarga red wine of $750 \mathrm{ml}$ capacity i.e., Rs. 246.

In this study $\mathrm{B}: \mathrm{C}$ ratio is highest for Viraat red wine of $180 \mathrm{ml}$ capacity that is 2.34 
followed by Viraat red wine of $750 \mathrm{ml}$ capacity that is 2.25 .

It can be concluded that all the brands are under risk free conditions and their value has been overtaken by their respective production levels.

Total sale was 188430 liters out of total production of 359010 liters $(57 \%)$. Total sale from red wine is 150.75 thousand liters $(80 \%)$ and from white wine it is 37.68 thousand liters $(20 \%)$.

\section{References}

Alexander, E. and Ellinger. 2011. Supply Chain Management Competency and Firm Financial Success. Journal of Business Logistics,32 (3).

Anderson,K. andWittwer.G. 2015. Asia's evolving role in global wine markets. Chinas economic review, 35: 1-14.

Andriotis. 2008. Measuring tourist satisfaction, A factor cluster segmentation approach. Journal of vacation marketing, 14(3): 221-235.

Castaldi, M.A. and Folwell. R.J. 1985. Economic returns and impacts: An historical perspective.

Chris, M.2019. Corporate finance and accounting

Das, K. 2010. Prospects and Challenges of Geographical Indications in India. The Journal of World Intellectual

\section{Property.}

Dev, J. 2009. Economics of finger millet (Elecusine coracana G.) production and marketing in peri urban area of Pokhara Valley of Nepal. development and agricultural economics. industry.Journal of Wine Research, 24 (3): 195-209.

Newton, K.S. 2015. Differentiation strategies and winery financial performance an empirical investigation. Wine economics and policy, 4(2): 88-97.

Prakash, T. N. 1986. A study on supply response, market margins and growth rates of Indian coffee. M.Sc. (Agri.) thesis (unpublished), University of Agricultural Sciences, Bangalore.

Razuana, A.R. 2015. Cleaner production implementation in a fruit juice production plant. Journal of Cleaner Production, 10: 215 - 221.

Rumintha, W.and Constanza, C. 2013.Management characteristics and the decision to internationalize: exploration of exporters vs. Nonexporters within the Chilean wine industry.Journal of Wine Research, 24 (3): 195-209.

Webliography

www, avensonline.org www.sulawines.com www.indiastat.com www.apeda.com www.sciencedirect.com National horticulture board FAO

www.karnatakawineboard.com

\section{How to cite this article:}

Pavitra Balundagi and Joshi, G. G. 2021. Analysis of Financial Performance of Different Brands of Nisarga Winery-A Case Study. Int.J.Curr.Microbiol.App.Sci. 10(01): 958-964. doi: https://doi.org/10.20546/ijcmas.2021.1001.116 